\title{
Environmental Policy for Road Transportation: Greenhouse Gas Emissions and Carbon Lands Nexus*
}

\author{
Shamsuddin Ahmed \\ York University, Toronto, Canada
}

\begin{abstract}
This paper explores the efficacy of environmental protection in road transportation that produces greenhouse gas (GHG) emissions as a result of vehicle travel frequencies in a region. Road transportation deduces the highest contributor of carbon emissions coupled with human interventions in the economic growth sectors that rather bear a perilous condition in property management exclusively in urban settlements or impervious lands. An association among the selected variables where population erraticism echoes a basic determinant of road transportation for energy use and vehicle travels increasingly succeeds carbon-dioxide $\left(\mathrm{CO}_{2}\right)$ emissions. Trends in regional gas emissions depict two pragmatic paradigms. First, at least four principal components are coherent and overriding in regional environmental protection to fulfil the common goal of measuring and monitoring climate smart land use. Second, a plausible land transportation policy pooled with environmental regulations is a complex one from economic development perspective as the higher the regional economic growth relates relatively higher GHG emissions in nature. It can be concluded that environmental protection from GHG is virtually regulated by three influences: population, energy usages, and vehicle travels which are deemed to be the spatial dimension of reducing global carbon emissions being caused from road transportation in a region.
\end{abstract}

Keywords: energy use, environmental policy, GHG (greenhouse gas) emissions, population, road transportation

Smart land use offers diverse benefits where environmental sector has an immense role in governing transportation regulations integrated with economic and social benefits, despite the fact that environmental policy and transit-base land use policy ought to be prevalent among the other policy issues. In environmental protection, transportation policy combines four fundamental components such as transport models, government objectives, institutions, and social groups (Santos, Behrendt, \& Teytelboym, 2010). These integrated components also entail policy instruments for environmental sustainability in road transport to one side from corporate strategies associated to physical multi-jurisdictional factors to impose a significant level of emissions generated from road transportation. This means that corporal policies such as transport and factors associated are conceivably the suitable implications of sustainable development in smart land use to control the level of

\footnotetext{
* This paper is an individual research and has been presented in the World Bank-2015 Land and Poverty Conference in Washington, D.C., USA, March 23-27, 2015. This paper does not necessarily represent views of the institution(s) where the author is affiliated and/or associated.

Corresponding author: Shamsuddin Ahmed, MS (environmental science), MPA (governance and public policy), MPPAL (public policy, administration and law), Grad Dip in Justice System Administration, and Cert in Applied Digital Geography and GIS (geographic information system), regular member of the Institute of Public Administration of Canada; research associate, York Centre for Public Policy and Law, York University; research fields: environmental science, public affairs, public policy, public administration, and GIS and remote sensing data applications. E-mail: shamsuddin.ahmed08@yahoo.ca.
} 
carbon dioxide $\left(\mathrm{CO}_{2}\right)$ gas emissions. The emissions of $\mathrm{CO}_{2}$ are extremely correlated with vehicle travel distances, and consequently, higher rate of vehicle travels has more gas emissions that affect land use suitability and human health and safety.

This paper aims to assess the effectiveness of environmental protection in road transportation. Physical elements such as greenhouse gas (GHG) emissions (equivalent $\mathrm{CO}_{2}$ ) transpired because of travel experiences (in vehicle kilometers or miles) in relation to energy usage and mobility frequency, or demographic intensity. Examination of factors or variables identified from this research relates two facets: the theoretical aspect of the effectiveness of road transportation incorporating a multi-criteria evaluation method, and the analytical dimensions of environmental protection policy apposite to the key indicators of road transportation in a region.

The readings of environmental policy integrated with transportation policy presumably notice three key aspects: the local sustainability especially to meet the present demand, the federal environmental regulations, and the international treaties. Information reviewed and analyzed helps to develop an initial framework for assessment on environmental protection applicable in transportation policy. Review of literature and available data also provides insights to address the strategic views for evaluating public policy components in environmental regulations that are effective for road transportation systems in a regional context while the considerable aspects are:

(1) Approach to evaluate environmental protection with institutional role such as local government and the stakeholders associated;

(2) Environmental policy instruments for sustainable road transport relevant to physical policies, pollution control, and compliance cost;

(3) Physical policies and multi-jurisdictional corporate strategies with respect to economic regulations, performance-driven compliance, and sustainable development;

(4) Government commitments in environmental regulations in regards to the constitutional framework, environmental law, and environmental compliance and international treaties.

The analytical dimensions of road transportation evaluation comprise of two major aspects: environmental protection regulations and road transport evaluation. The environmental protection strategy in smart land use commonly refers what the author realizes from five interrogative views as the key aspects. Firstly, conflict analysis that is characterized by technical, socioeconomic, environmental, and political value judgments to reach an acceptable compromise solution (Orr, Emerson, \& Keyes, 2008). Secondly, adequate evaluation methodology through multiple criteria evaluation technique that aims to provide a flexible but systematic way of dealing with quantitative and qualitative multidimensional environmental effects of decisions based on transparent information (Munda, Nijkamp, \& Rietveld, 1994; Tzeng, Lin, \& Opricovic, 2005). Thirdly, participation of multiple stakeholders from both the public agencies and the local communities to avoid or minimize the conflicting interests as institutional approach (Rugman \& Verbeke, 1998; Hazopoulou \& Miller, 2008). Fourthly, designated area of interests where environmental protection is needed or questioned on sustainability in relation to spatial context such as population intensity, energy usage, and GHG emissions. Finally, a timeframe for effective resolution and efficient compromise of the problem associated to spatial and environmental upsets because of road transportation dynamics.

Approach to environmental protection evaluation of the potential transportation elements deemed to be comprehensible on policy implications while sustainable transportation policy aims for policy effect to 
eliminate or control $\mathrm{CO}_{2}$ emissions at a certain level. Santos et al. (2010) note that the road transport sector has a positive influence on reducing $\mathrm{CO}_{2}$ emissions to implement a sustainable transport policy with an integrated policy option, for example, transit-base land use planning helps aggregate demand of transportation that in fact relieves reduced level of emissions in proportion to the population and mobility. The relevance of environmental policy in the transportation sector is to control the amount of emissions likely in two aspects. One is for safe transportation as a public utility system to contribute in a national commitment ensuring that environmental sustainability is measured with the millennium development goals (MDGs) of the United Nations (Mertens \& Wilson, 2012, p. 19) at the local level. The other is international context, for example, Canada's consensus with the Copenhagen Accord (December 2009) that aims to reduce the country's GHG emissions to 17\% below 2005 levels that is 607 Mt (megatons) (Environmental Commissioner of Ontario, 2012; Environment Canada, 2013a). According to Environment Canada, economic sectors are the major producers of gas emissions where transportation sector, as one of the key areas of the economy, produces $24 \%$ of Canada's total emissions. It indicated that the emissions in the transportation sector had been increased by $36.4 \%$ (53.0 Mt) from 1988 (or 1990) to 2008. Canada's annual emissions characterize a firm intensification in the first 15 years of this period and fluctuating emission levels between 2005 and 2008 occasioning a sharp decline in 2009, but subsequently increase thereafter. Overall, national level total GHG emissions in 2013 were 726 (Mt) of carbon dioxide equivalent $\left(\mathrm{CO}_{2} \mathrm{e}\right)$, or 18\% (113 Mt) above the 1990 emissions of $613 \mathrm{Mt}$ (Environment Canada, 2013b).

In this paper, the author reviews publicly available data and statistical records on road transportation emissions as analogous to total populations, energy consumptions, and vehicle travel distances-in order to explore the determinants of the GHG emissions in Ontario Province as a region especially in comparison with the Canada nationwide situations. This research delivers to comprehend data with the response variables, and the control or explanatory variables associated to $\mathrm{CO}_{2}$ gas emissions from road transportation. Analyses of data indicate that environmental protection from GHG emissions is virtually controlled by three factors: population, energy usages, and vehicle travels which are deemed to be the spatial dimension of greenhouse gas emissions produced from road transportation.

This paper is organized in five sections: (1) review of theoretical grounds of environmental evaluation considering the multi-criteria appraisal methods and the policy implications in transportation (Section 2); (2) identification of preliminary variables associated to the environmental, demographic, and economic factors (Section 3); (3) interpretations of the key variables associated to land transportation and environmental protection (Section 4). Analyses of relational attributes of road transportation emissions being instigated from physical and local responses identify four indicative criteria variables: population and business; energy usage; travel experiences (vehicle travels, MVKm); and GHG emissions (GHG emissions in Mt of $\mathrm{CO}_{2} \mathrm{e}$ ). Data analysis implicates newly generated attributes and Excel worksheet for evaluating the decision variables; (4) Section 5 offers the concluding remarks with plausible suggestions for the implication of integrated road transportation policy for environmental protection which are inevitable for smart land use. This section incorporates the subsequent sections of the paper that is rationally organized into four major illustrations and the sub-sections as sketched in Figure 1. 


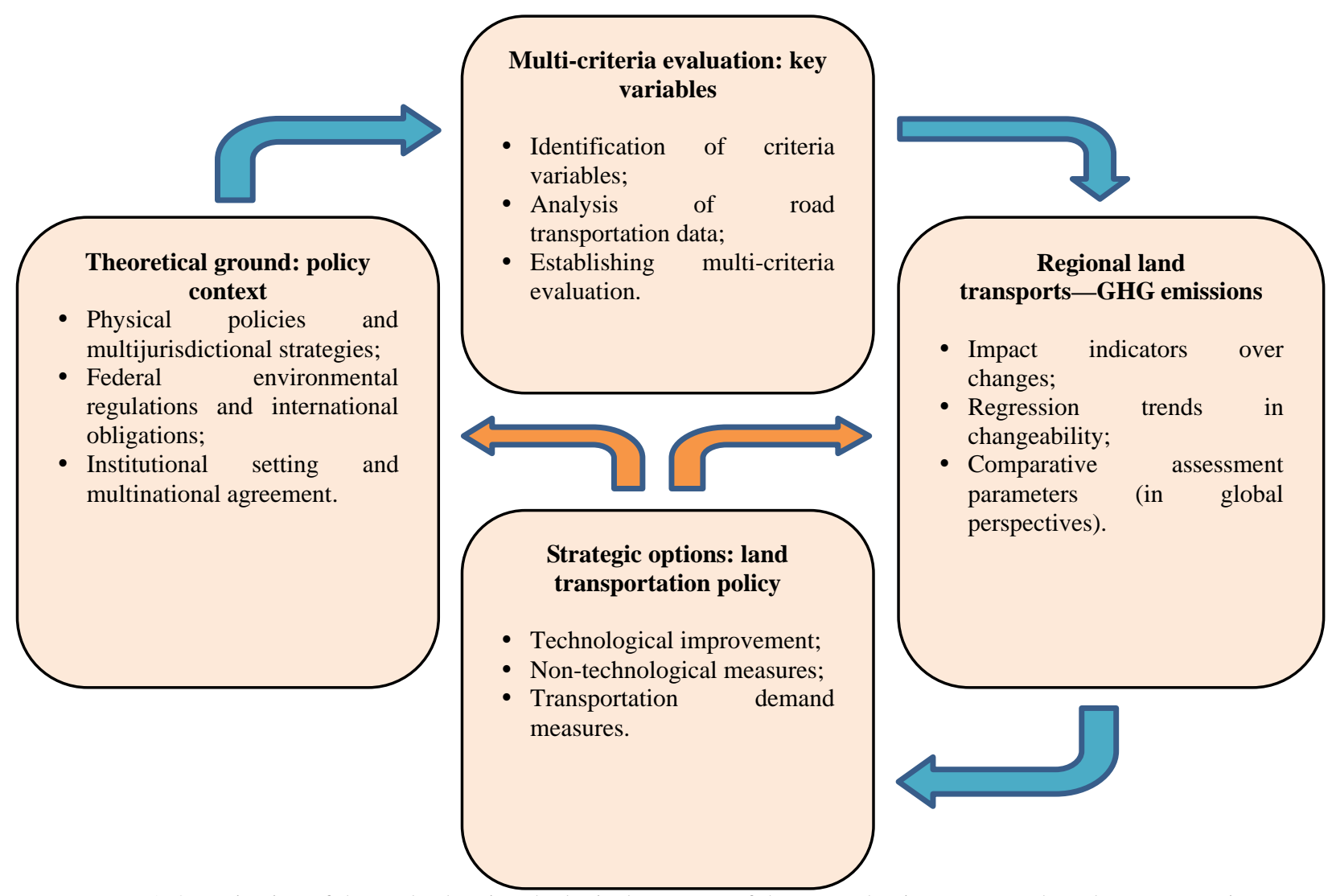

Figure 1. Organization of the study showing the logical structure of the paper that incorporates the subsequent sections with four major illustrations.

\section{Environmental Protection and Road Transportation Policy}

Environmental regulations become policy instruments for environmental protection, which is applicable in two regimes: non-regulatory approaches and regulatory approaches (Peachlke, 2012). This illustration defines three types of non-regulatory approaches namely indirect, participatory, and authoritative approaches statutory delineated and separated from the delegated regulatory regime. The disadvantage of non-regulatory approach is rather inconvenient because of an increasing administrative cost as it involves traditional method that is often challenging and time-consuming to determine the value of summative measures for GHG emissions in lands carbon nexus. Regulatory approach, for example, fuel use efficiency is an applicable means of effective regulatory measure that is indispensable with multi-criteria analysis of alternatives to reduce the pollutions produced from gas emissions (Tzeng et al., 2005). This notion of pollution control in the transportation records verifies few measures, of which, less fuel energy usage per mile or kilometer results lower emissions, and subsequent decrease in emissions and hazardous waste produced in refineries. For analytical motives, this section reviews three aspects: the policy context-physical policies and multi-jurisdictional strategies, the legislative framework of federal environmental regulations and international obligations, and the corporate strategy—international environment and multinational agreement.

\section{Policy Context: Physical Policies and Multi-jurisdictional Strategies}

In 2012, Transport Canada addresses the environmental policies and regulations for federal and provincial transportation sectors including the road transportation. While government initiatives in reducing greenhouse gas 
emissions and other harmful transportations affect the environment, GHG emissions from road transportation includes passenger and commercial or truck vehicles where 25\% of Canada's total emissions appear from passenger vehicle. Environment policy develops regulations and programs for two key reasons: improving the use of sustainable transportation and reducing the negative environmental impacts. Examples are ecoTransport Strategy and the Motor Vehicle Fuel Consumption Regulations (Transport Canada, 2013). These programs provide regulatory guidelines for a long-term environmental vision and trend for road transportation. As policy implication, the provincial or regional programs accumulate federal emissions regulations to control emissions from in-use vehicles and establish the standards of emissions by vehicle type particularly mentioned in the Motor Vehicle Safety Regulations under the Canadian Environmental Protection Acts (1999). According to the Conference Board of Canada (2013), diminishing a substantial amount of GHG emissions is yet challenging for Canada resembling Australia and the U.S. because of the total GHG emissions that have been increased 17\%, although a measurable decrease in per capita GHG emissions is nearly 5\% between 1990 and 2010. Therefore, policy implication in environmental protection by reducing GHG emissions is not yet sustainable in Canada, USA, and Australia as these countries remain as the uppermost performers in absolute GHG emissions prevalently from the land transportations as well as other economic sectors.

The UN Commission on Environment and Development (UNCED) defines the term "sustainability" on sustainable development, which is "a development that meets the needs of the present without compromising the ability of future generations to meet their own needs" (Santos et al., 2010, p. 48). Hazopoulou and Miller (2008) noted that most policy appraisal, regardless to environmental protection issues, occurs without the use of formal evaluation tools since it only goes through public discourses and professional judgments. Ineffective implementation of policies is often coaxing by the meagerness of integrated policymaking process. Frequencies of polluting agents are relatively higher in urban areas than that of the rural areas. Institutional accountability of Ontario road transportations vexed, in terms of environmental compliance with local government infrastructures and on public health and safety issues, can be described by strategic framework conceivably in four parts: federal government regulations in environmental protections, provincial government policies in growth management, international obligations as cross-border issues, and the corporate strategies in policy compliance to perform the business framework that the designated institutions adopt to determine the appropriate choice of action in response to both the national statuary regulations and the international environmental pressures (Rugman \& Verbeke, 1998). Nevertheless, the federal government has paramount role over other policies and programs which are designated to the provincial legislation and the municipal acts that deliberate physical or tangible tools for environmental measures. For example, Ontario Planning Legislation and Ontario Municipal Act are the local governance regulatory charters as riveted from the provincial and regional environmental regulations, international environmental treaties, and the economic development grounds needed for multi-jurisdictional policy implications especially the regional road transportations, growth management and environmental protection in climate smart land use effectiveness.

In terms of economic regulations, multi-jurisdictional policy retains two-sided responsibilities. Transport Canada is a key regulator and policymaker, while the provincial government responsibility includes joint economic regulation of interprovincial transportation issues in trucking, construction, and maintenance of major highways. Vehicle licensing and inspection and enforcement of traffic rules are also incorporated under provincial jurisdiction. Stakeholders and general public consultations have substantial outcomes for the federal 
government, the provincial authority, and the transport agencies when they meet the stakeholders for policy development and implementation in a participatory manner. Therefore, the central role of the federal government in the collection and dissemination of information is particularly critical as air pollution can have significant trans-provincial and international effects. Nemetz (1986) contended that centralized collection of regional and national time-series data is indispensable in the evaluation of environmental damage and formulation of appropriate technological and policy responses.

Nonetheless, symmetries of historical environmental data often appear lack of aptness in relational attributes that would have persevered adequately for statistical analyses and trending at current state to understanding the quantitative changes and the qualitative dealings succeeded over time and desirable in future particularly at local and regional environmental compliance in land transportations. Recent projection in environmental regulation shows five leading pollutants: carbon monoxide, hydrocarbons, particulates, nitrogen oxides, and sulphur oxides which are associated to aid emissions in the atmosphere. For transportation system, the emissions are measured with $\mathrm{CO}_{2} \mathrm{e}$ in tonnes that have edgings from both national and international environmental obligations.

\section{Legislative Framework: Federal Environmental Regulations and International Obligations}

The Parliament of Canada delivers the new and updated regulatory commissions that are required by the respective government departments in respect of public and law affairs. A parliamentary research by Douglas and Hebert (1999) indicated that environmental regulatory framework of the transportation system is updated in 2010 through Bill C-32 under the Canadian Environmental Protection Act (CEPA), 1999. Bill C-32 includes the amendments applicable to the Canada Transportation Act (S.C. 1996, c. 10) to contribute the sustainable development by practicing the pollution prevention plan (Clause 50-56) and the national emissions mark (Clause 150-152).

In the constitutional framework, environmental regulations in Canada reveal a statutory authority in environmental control as enumerated by Section 91 and Section 92 of the Constitution Act, 1982 (Monahan, 2006). This provides rights of the federal government authority to make law for "the Peace, Order and Good Government of Canada", Section 91, which empowers the federal government to deal with all forms of pollution at national level, provinces, and international borders. On individual emergency case, this law also grants the federal government to handle large scale emission of poisonous substances into the environment. The statutory regulations retaining the environmental issues explain two public laws: the common law and the criminal law. The common law retains a prominent character in the protection of individual rights and the environmental concerns from certain type of hazards. Virtually, the British common law tradition is manifested in all provinces except the Province of Quebec which has implemented the Napoleonic Code in the matter of civil litigation. The criminal law is the domain of federal government under Section 91 of the Constitution Act. It, including the Procedure in Criminal Matters where Section 92 provides provincial legislatures jurisdiction, is enforced by the provincial attorney general. Violation in domestic environmental regulations and international environmental treaties support the statutes for both the criminal matters and the civil affairs. Therefore, GHG emissions generated from road transportation sector need environmental protection for safety with respect to the population, energy use, and vehicle travels.

In international obligations, Canada's agreement with the Kyoto Protocol was to reduce its annual GHG emissions (from all sectors) during the 2008-2012 periods to 6\% below 1990 level (Poudenx, 2008, p. 903). 
Canada's Copenhagen Accord in December 2009 aims to reduce the GHG emissions to 17\% below 2005 level at $607 \mathrm{Mt}$. This has become a challenging practice at the corporate level to grasp the obligations due to the local settings in population, urban density, and energy usages.

\section{Corporate Strategy: Institutional Environment and Multinational Agreement}

Multinational corporate strategy (Rugman \& Verbeke, 1998) underlines the environmental side of "The North America Free Trade Agreement” (NAFTA) that connects Canada with Mexico and the United States of America as a major breakthrough with international trade agreement that was entered into force in 1994. The major upshots of this agreement link a broad aspect through the NAFTA "Commission on Environmental Cooperation” (CEC) for incorporation of environmental issues and establishing a diplomatic means to administer trade and environmental interaction. The linkage of physical or tangible transportation policy is more focused on economic and trades affairs. However, environmental regulatory frameworks on cross-border issues relate two attitudes: the government actions and the industry standards.

In the government actions, air pollution control as a major cross-border issue, Nemetz (1986) clarified that the coincidence and pattern of air pollution control in Canada differs from the system that characterizes the management of waterborne pollutants. Thus, the Clean Air Act of 1971 like Canada Water Act provides the principal federal legislative instrument, for implementation of any infrastructure development or construction work relevantly associated with the corporate authority, like transportation sector. This also refers government action to limit a maximum amount of emissions from the stationary sources such as commercial or residential buildings and industries. In Ontario, the international environment and multinational corporate strategies are also subject to the Environmental Protection Act (R.S.O. 1980, c141)-that regulates the multinational corporate strategies associated to the road transportation sector, such as Bill C-32 under the Canada's Environmental Protection Acts. As an industry standard, design, construction, and functioning of on-road vehicles are regulated by Motor Vehicle Safety Act (MVSA) of 1970 that was amended in 1993 where Transport Canada establishes national emissions standards which are based on Canadian Environmental Protection Act (CEPA, 1999) that came into effect in 2000. According to a CBC (Canadian Broadcasting Corporation) media news dated July 1, 2010 (CBC News, 2010), Ottawa, the federal government headquarter, is cracking down the vehicle emissions to comply with U.S. standard on cross-border issues although the absolute GHG emissions have been perplexing to bring at certain standards that are required from international obligations.

All provinces and territories comply these standards in the transportation sector and the regulations of emissions from vehicle have become the responsibility of Environment Canada. International Organization for Standardization (ISO) in Geneva, which has members from over 50 nations, develops a set of international environmental management for business, for example, ISO 14000 (Nemetz, 1986). Nevertheless, ISO 14000 is not robust enough to follow the compliances with international environmental legislation toward a more proactive management of corporate environmental assets and liabilities. The effectiveness of environmental protection for road transportation could be a prior deliberation, considering the multi-criteria evaluation method to be based on local settings as spatial dimension such as population density, fuel demand, and the ecological patterns. Thus, this paper also explores the evaluation components, among others, urban density (by population), fuel efficiency (energy use), and transit systems (vehicle travels) to determine the variability in the effectiveness of environmental protection over time. 


\section{Environmental Evaluation Criteria}

Since the environmental evaluation for road transportation is necessary to determine the effectiveness of both the environmental governance regulations and the land transportation policy, it is obligatory to control the GHG emissions generated from Ontario road transportation system. Section 2, discussed earlier, provides understanding of the circumferences to measure the effectiveness of road transportation from environmental control point of view. It is indispensable to identify the relational attributes based on the historical trends of environmental, demographic, and physical data. Observation of trends and patterns of performance such as change dynamics and factors associated to the context evaluation of a geographical phenomenon helps to recognize the variability of resource-needs and resource-use assessment. For this purpose, the context-input-process-product (CIPP) model (Mertens \& Wilson, 2012; Wholey, Hatry, \& Newcomer, 2010) is an important viewpoint to determine the extent of the problems with both qualitative and quantitative inputs. Considering the CIPP method, this stage identifies five variables, and later other response variables with sensible attributes which can be covered from the subsequent illustration. This section establishes evaluation criteria for road transportation in Ontario presumably with three solutions: the identification of key variables, the preliminary analysis of Ontario road transportation data, and the multi-criteria evaluation based on the spatial dimension with respect to geographical extent.

\section{Identification of Criteria Variables}

Reviews of relational attributes of road transportation emissions being instigated from physical and local responses can be identified at least with four indicative criteria variables:

(1) Population and business that may reflect the population growth in a geographical region as a basic indicator to road transport that generates traffic volumes (Statistics Canada, 2012);

(2) Energy usage, where quality and availability determine the appropriate outcome of transportation from environmental and local point of view, as poor supply and poor quality of energy results dichotomous bids for environment, such as higher concentration of air pollutants (Natural Resources Canada, 2012);

(3) Travel experiences refer million vehicle kilometres (MVKm) of vehicle travel distance to be based on estimated traffic volume and the corresponding lengths of the road sections that are monitored and maintained by the respective department (Ontario Ministry of Transportation, 2008; Transport Canada, 2013);

(4) Gas emissions indicate GHG emissions in Mt of $\mathrm{CO}_{2} \mathrm{e}$ (Natural Resources Canada, 2012). GHG emission is also estimated per person per year (in kilograms, 1 tonne equals 1,000 kilograms).

\section{Analysis of Road Transportation Data}

This preliminary analysis offers to establish the most paramount criteria variables which ought to be acceptably associated to draw a conclusion to distinguish the categorical data in a regional context in comparison with the federal or national data connected to land transportations dynamics. Findings from data analyses including statistical dispersions and regression outputs demonstrate association among the selected variables where population erraticism is a basic determinant of road transportation for energy use and vehicle travels that increasingly succeeds $\mathrm{CO}_{2}$ emissions. These variables have a propensity over linear association but arguably demonstrate a non-linear relationship presumably with cubic or quartic functions that provide the best fit to estimate the $\mathrm{R}$-square $\left(\mathrm{R}^{2}\right)$ values.

Conversely, Figure 2 illustrates three elements such as energy use, vehicle travels, and GHG emissions that are non-linearly related over time as there other factors are presumably involved. For example, 
energy usage in transportation is subject to the market supply and use demand, number of vehicle travels, energy prices, and transport mobility or total travel-distances. Correlations of variables with comparative scenario in Ontario and Canada are shown in Figure B-1 (in Appendix A), which indicates that the higher the road transports (or vehicle movements), the higher the GHG emissions appear. The statistical regression analyses describe that the association between the year (independent variable) and the corresponding response variables (dependent variables) is non-linear, hence appears to be suitable with quartic functions.
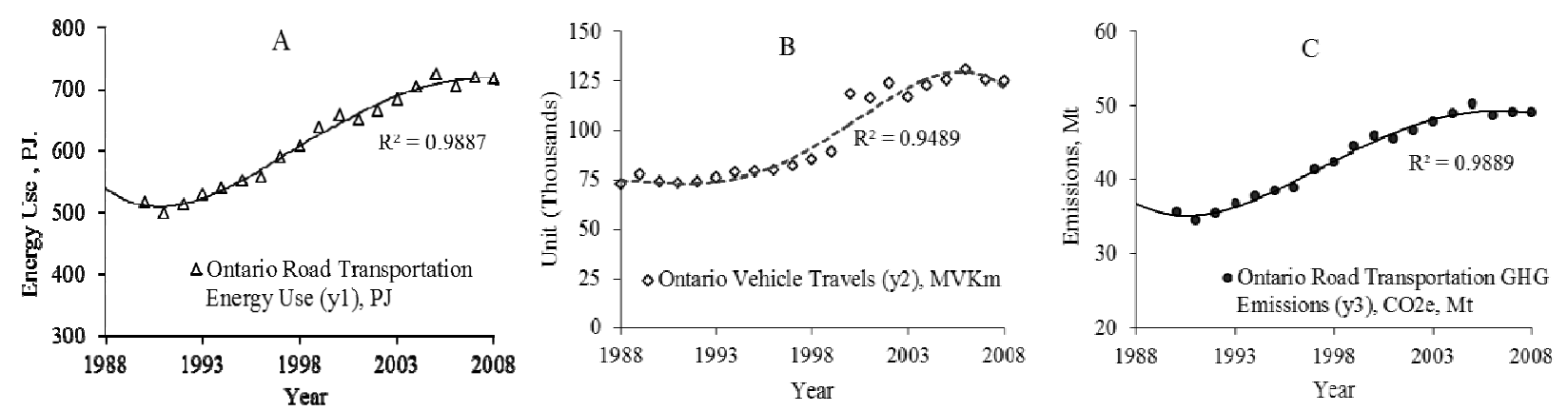

Figure 2. Trends in Ontario road transport, 1988-2008 (A: energy use, B: vehicle travels, and C: GHG emissions). These illustrate that the distribution is non-linear and presumably depict the best fits of data variability with quartic function. There is a tendency of a linear relationship among the variables where the yearly variability is somewhat irregular over time. Source: Natural Resources Canada (2012). Note. Data source described in Figure A-1 and Figure A-2 (in Appendix A).

\section{Establishing Multi-criteria Evaluation}

As transportation relates environmental protection, multi-criteria evaluation is essentially needed to resolute environmental, economic or physical conflict analysis. Evaluation of environmental pollution measures is imperative with mixed-method illustration as both qualitative and quantitative multi-criteria analyses (Tzeng et al., 2005; Munda et al., 1994)—which primarily focuses on pragmatic paradigm considering the evidence-based information and subsequently provides understanding on constructive paradigm in viewing the priority attentions in environmental protection in land transportation. Based on the varied correlation observed among the criteria variables, reflection of data analysis delivers to build other attributes, which the author terms here as redistributive and coherent factors (see Figure B-1 in Appendix B), which are important in multi-criteria evaluation with respect to spatial dimensions connecting the provincial and federal effects in GHG emissions. These variables are:

(1) Ontario population as proportion of Canada's total population (percent);

(2) Ontario road transport—energy usage in proportion to Canada's road transport energy usage (percent);

(3) Ontario road transport GHG emissions as proportion to Canada's road transport emissions (percent);

(4) Ontario road transport GHG emission as proportion to Canada's all sectors GHG emissions (percent);

(5) Ontario road transport GHG emissions per million populations (Mt);

(6) Canada road transport GHG emissions per million populations (Mt);

(7) Yearly change in Ontario road transport GHG emissions (percent);

(8) Yearly change in Canada road transport GHG emissions (percent);

(9) Yearly change in Ontario provincial population (percent);

(10) Yearly change in Canada's total population (percent). 
Correlations of the above generated data variables (see Figure B-2 in Appendix B) demonstrate that four redistributive and coherent variables are overriding in regional environmental protection applicable in Ontario road transportation. These measurable multi-criteria variables in Ontario Province or region in comparison with the Canada national statistics are: provincial GHG emissions per million population, federal GHG emissions per million population, provincial proportion of population, and provincial proportion of road transport emissions. Statistical multiple regression analyses (shown in Figure C-1 and Figure C-2 in Appendix C) indicate that both population and energy usage in road transportation are dynamic forces in GHG emissions in a region.

\section{Regional Land Transportations and GHG Emissions}

The foregoing analyses suggest the importance to evaluate the effectiveness of environmental protection considering the magnitude of energy emissions that have diffused from land transport vehicle travels resulting from the total population and energy use. This section offers analyses of land transportations affect from GHG emissions in a regional context in comparison with the federal or global compliance in environmental protection regulations. With a view to exploring data, this research ruminates the Province of Ontario in Canada as an environmental or territorial region for analytical purpose. Data analyses and findings depict two pragmatic paradigms in the effectiveness especially in recent trends of gas emissions generated from Ontario road transportation. One example is the proportion of GHG emissions per million populations. The other practicality is the proportion of Ontario road transportation emissions with respect to the Canada's road transportation and all economic sectors' GHG emissions. We can stipulate these constraints in three dimensions: the impact indicators over the changes, the regression trends in changeability, and the comparative assessment parameters.

\section{Impact Indicators Over Changes}

The sensible reason behind the indecisiveness of land transportation impact indicators is imaginable in Ontario road transportation that is in proportion of the population needs to be reviewed with the environmental protection measures with monitoring and auditing system, even though the environment protection is primarily the responsibility of the federal government. Empirical evidence shows that Ontario's road transport sector contributes $11 \%$ and $7.5 \%$ higher in $2008(6.72 \%)$ than that of the emissions produced respectively in 1988/1990 (6.04\%) and in 1998 (6.25\%).

Figure 3 shows cumulative increase in energy usage and gas emissions in Ontario and Canada, indicating that the yearly changes are analogous in proportion to energy usages. Figure 4 describes that Ontario road transportation is an upward trend of emissions being contributed lower in proportion to Canada's all sectors responsible for GHG emissions, while the proportion of Ontario population shows a downward trend after the year 2005 as demonstrated in Figure 5. Data regression analysis (Terrell, 2012; Moore, 2010) fits the non-linear trends in yearly change indicators, for example, in population, energy use, and GHG emissions. The patterns in GHG emissions for the per million population and the proportion of total in Ontario are similar, while the annual change in population proportion slightly shows a different trend, however, fits the models at 4th order polynomial or quartic function.

Figure B-2 (in Appendix B) demonstrates changeability in data. Apparently, in 2008, the emissions which appear from Ontario road transportation show lower level than that of the Canada wide road transportation, 
even though the national level statistics demonstrates the reduced energy usages, higher population, and higher vehicle travel as compared with 1988/1990.
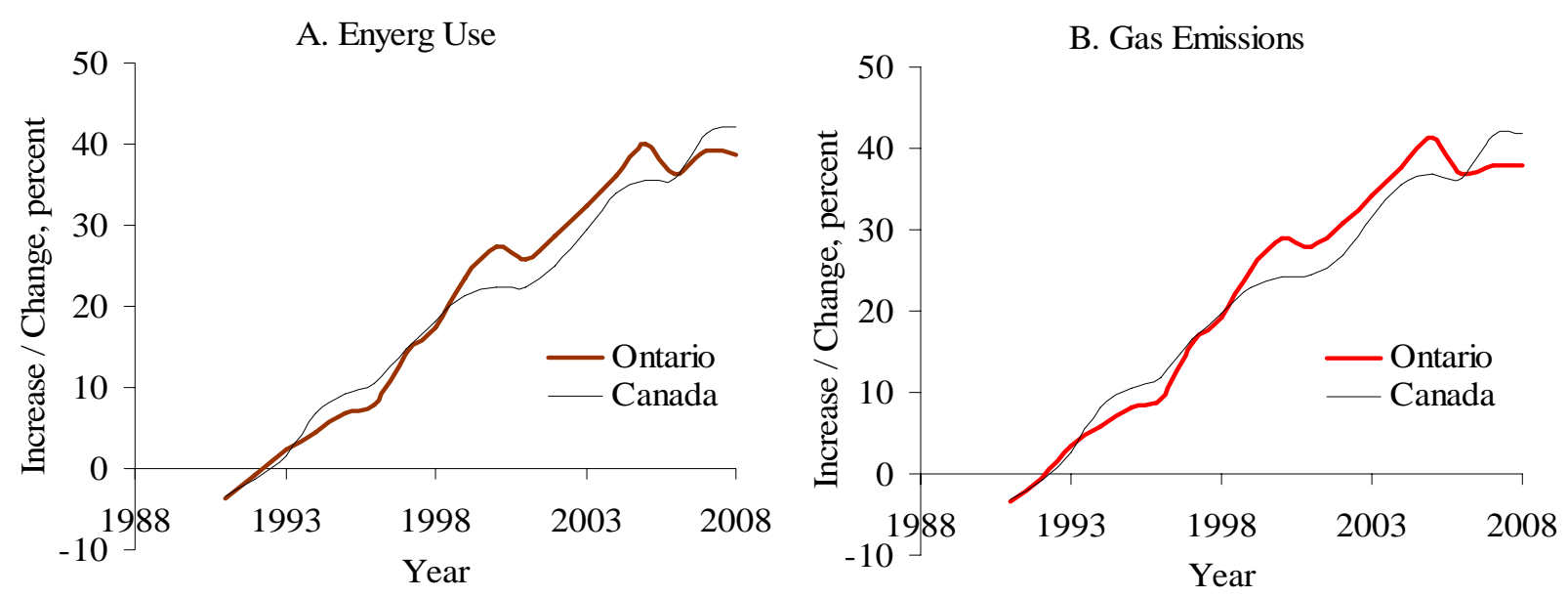

Figure 3. Cumulative changes in road transportation in Ontario and Canada from 1988/1989 to 2008 (A: energy use and B: gas emissions). Source: Natural Resources Canada (2012). Note. Data source described in Figure A-1 and Figure A-2 (in Appendix A).
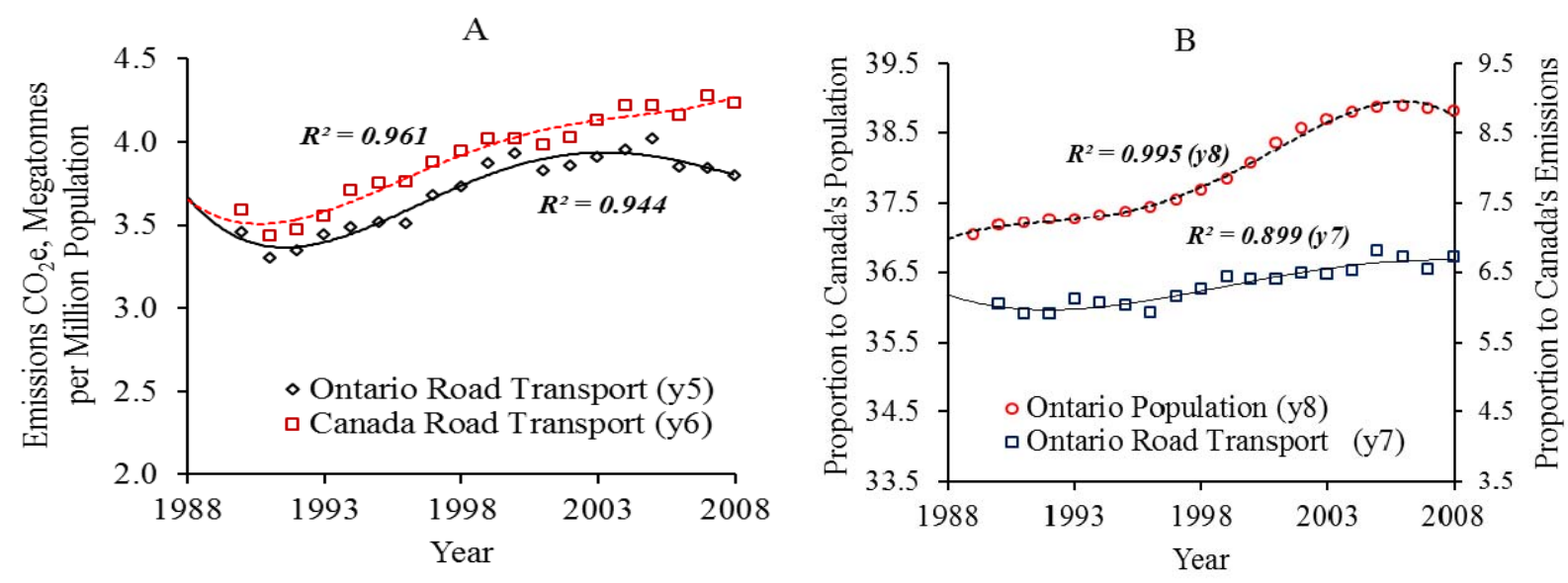

Figure 4. Trends in population and road transport emissions over time [A: Ontario and Canada road transportation GHG emissions per million population, B: Ontario population and Ontario road transportation GHG emissions as the proportion of Canada's total population and total emissions (from all sectors)], 1988-2008, where the emissions over time are non-linear and demonstrate at least a quartic function of association. Note. Data represent historical data as demonstrated and indicated with the source of data in Figure A-1 and Figure A-2 (in Appendix A).

\section{Regression Trends in Changeability}

The fundamental outcome of this model is to fetch the best fits in data variability that is expressed by $\mathrm{R}^{2}$ value. The importance of Figure 4(B) is to assess a parallel distribution pattern between the proportion of Ontario population and the proportion of Ontario transport emissions with that of national population and all sectors' emissions over time, which shows a high correlation value, $r=0.939$ as exhibited in Figure B-4 (Appendix B). Thus, annual instability in energy use, GHG emissions, and designated population variables involves multiple factors which are chiefly the energy use and vehicle travels dominant to the road transportation. Figure 5 describes the facets in vehicle travels versus GHG emissions in Ontario road transportation in comparison with the federal transportation data. Ontario road transportation data display 
irregular distribution of the trends presumably because of dependability in data. From 1988 to 1999 (period y1), where the $\mathrm{R}^{2}$ values for both Ontario (region) and Canada (national) are more or less the same, ostensibly indicates strong linearity in the yearly increasing rate in GHG emissions.

Period y2, from 2000 to 2008, demonstrates no significant correlation for Ontario while showing higher emission rate from the vehicle travels. Commonly, the association between vehicle kilometers and GHG emissions is similar in pattern, although Ontario yields slightly lower emissions rate akin to yearly vehicle travels. Likewise, multiple regression analyses outputs indicate that Ontario road transportation GHG emissions have no significant correlation with population and vehicle travels as shown in Figure C-1 (in Appendix C), whereas the regression outputs for Canada road transportation emissions demonstrate relatively a less measurable association with the vehicle travels as presented in Figure C-2 (in Appendix C).
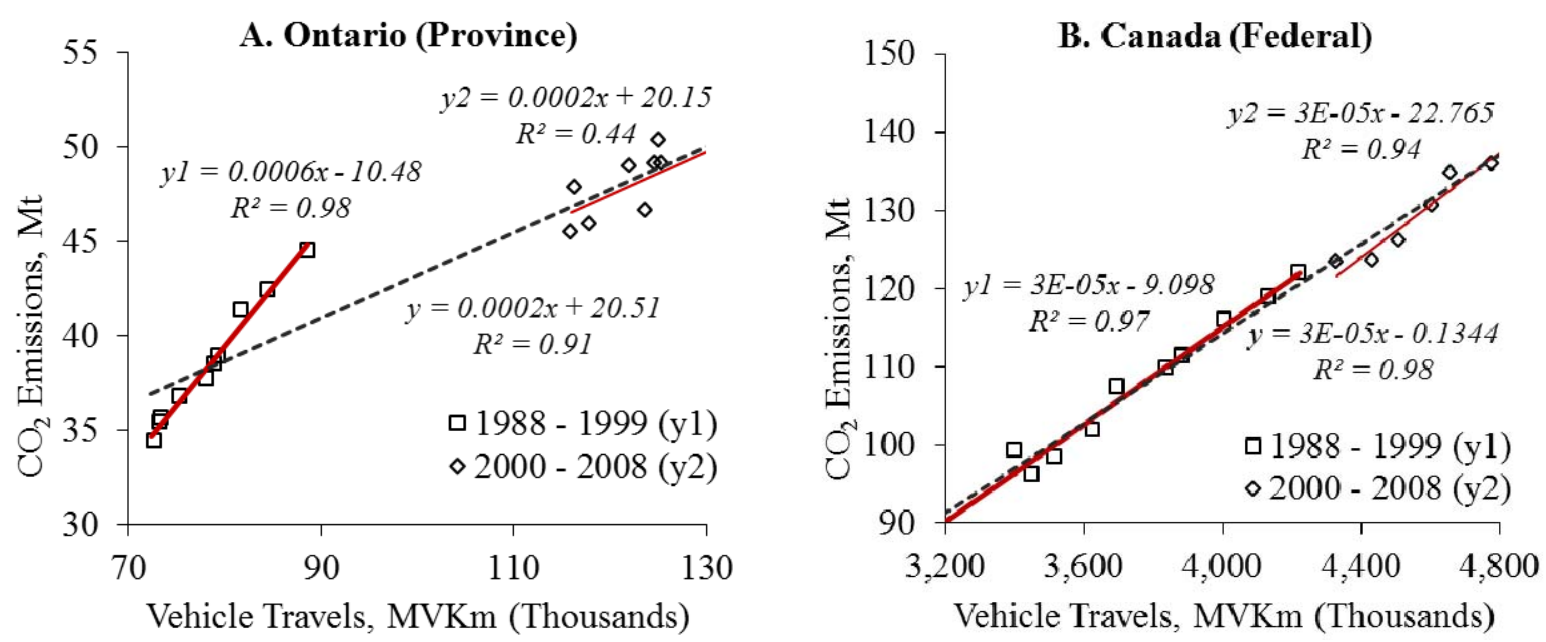

Figure 5. X-Y plots showing of the relationship between vehicle travels and $\mathrm{CO}_{2}$ emissions (A: Ontario Province and B: Canada nationwide). Sources: Ontario Ministry of Transportation (2008); Natural Resources Canada (2012). Notes. Source of data is described in Appendix A, where, vehicle travels indicated by Ontario Ministry of Transportation (2008); $\mathrm{CO}_{2}$ emissions indicated by Natural Resources Canada (2012).

\section{Comparative Assessment Parameters}

In 2008, Canada nationwide road transportation indicates an increasing gas emissions of $17.9 \%$, which is double than that of Ontario's road transport emissions increased (9.8\%) from 1988/1990. Simply, if we observe the finding as demonstrated earlier in Figure 3, the dispersions in annual average increase of $\mathrm{CO}_{2} \mathrm{e}$ emissions are $0.0465 \mathrm{Mt}$ (46.5 kilograms) and 0.0346 Mt (34.6 kilograms) per million population respectively from Canada road transport and Ontario road transport as computed from 1988/1990 to 2008, whereas in 2008, the level is at 3.80 Mt in Ontario and 4.23 Mt in Canada. This finding notices that GHG emissions from Ontario land transportation have somewhat improved situation than that of the Canada's nationwide land transportation emissions - which can be an implicit effectiveness in environmental protection in Ontario road transportation.

Nevertheless, this finding has varied outcome if we consider the populated areas by low density (suburban fringe) and high density (urban core). Norman, Maclean, and Kennedy (2006, p. 15) clarified the GHG emissions that indicate 5,310 kilograms (5.18 tonnes) in low density areas and 1,440 kilograms (1.44 tonnes) in high density development areas of City of Toronto automobile and public transits. The other observation is that the average increase in Ontario population is relatively higher than that of the overall Canada's population since other provinces and territories have less populated than Ontario. Thus, the analysis denotes a negligible 
effectiveness in environmental control performance even though there has been a slight decrease in Ontario population after the year 2005. Further illustrations can be seen in Figure B-4 in Appendix B.

In fact, the existence of $\mathrm{CO}_{2}$ emissions is relatively downright concerning the urban compounds such as the low density urban and the high density urban. Therefore, the estimation of emissions per person may not be suitable to the intensity of emissions that are countable for human health measures. This argument can be examined with two situations: the atmosphere and the vegetation. Both environments have high absorbance capacity depending on the atmospheric condition (e.g., wetness and winds) and the vegetation intensity (e.g., perennial, temporal, or seasonal trees) - which have higher permissibility of $\mathrm{CO}_{2}$ absorbance in low density urban or suburban compound that calculates higher rate of emissions per person per year. In other words, emissions absorbance capacity is absolutely low in the high density unbans because of high population density and high buildings compactness. Therefore, it is crucial to estimate the intensity of $\mathrm{CO}_{2}$ emissions and evaluate the effectiveness of emissions control considering the regulatory measures indicated in the Canadian Environmental Protection Acts (CEPA, 1999). CEPA inference in land transportation would apparently convey four key factors: provincial demographic patterns (of population trends), vehicle emissions standardization (on fuel efficiency), transit-base land use (on mobility diversity), and local vegetation coverage (for higher absorbance of $\mathrm{CO}_{2}$ emissions in nature).

Transportation policy combined with environmental protection regulation is a complex one from economic

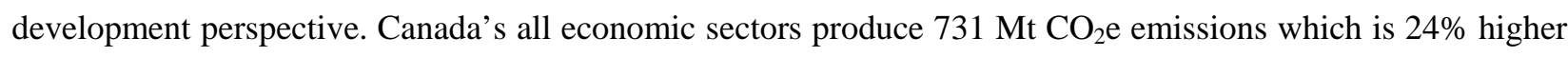
than 1988/1990's emissions (589 Mt) while this changes in comparison, on an average estimation, Canada nationwide and Ontario region have increased GHG emissions $41.9 \%$ and $37.9 \%$ in the land transportation sectors in 2008, respectively. This means that road transport sector is a big producer of GHG emissions at climate change level, although Ontario land transport sector has relatively lower greenhouse emissions in comparison with the national road transportation's emissions increase level (41.9\%) in 2008 as a benchmark.

Similarly, in 2008, GHG emissions reach per million population at 3.80 Mt and 4.23 Mt respectively in Ontario and Canada. This means each year, on an average, every people living in locality surrounded by 4.0 tons or 4,000 kilograms of GHG emissions consumption in Canada-which is categorically an alarming environment for human health and safety (see Figure 4 and Figure B-3). Besides, the challenging issue is that Canada's emissions reach at $731 \mathrm{Mt}$ in 2008 that shows 24.1\% higher than the 1990 level emissions (589 Mt) expected in accordance with the Copenhagen Accord.

Change in regression trends of federal and provincial population indicates that demographic configuration is the primary influential factor in GHG emissions in road transportation sectors (see Figure 3), while vehicle emissions standardization, transit-base land use, and local vegetation coverage need appropriate measures to control the increasing level of emissions. Industry standard automobile for road transportation (e.g., vehicle emissions rate) is configured as per provision of the domestic regulations and the international obligations discussed earlier. As environmental value allies in ecological impact, suitable vegetation coverage aids the effect of environmental policies on energy consumption and GHG emissions especially from the urban road transportation and the regional and global context. Many authors (Poudenx, 2008; Norman et al., 2006; Friesen, 2003; Munda et al., 1994; Tzeng et al., 2005) clarified the options in numerous attributes but without emphasizing the needs for vegetation coverage that would balance the increasing GHG emissions generated from road transportation. 


\section{Conclusions}

The prevailing circumstances in environmental policy for road transportation constitute the determinants of GHG emissions and carbon lands nexus at least by three facades. Firstly, impact indicators over changes in GHG emissions point toward the indecisiveness in road transportation in proportion of the population and business mobility ought to be perused with the environmental protection regulations through optimal monitoring and auditing system by the designated regional governments. Secondly, regression trends in changeability demonstrate a parallel distribution pattern of GHG emissions in road transport corresponding to total population and all sectors' emissions over time. Lastly, comparative assessment parameters indicate that nationwide road transportations have variant levels of gas emissions than that of the regional data because of change in total population.

Evaluation of transportation data and relative attributes warn that the effectiveness of environmental policy is yet impassable to the bearable measures in GHG emissions control at the local or regional levels and in the global policy context chiefly because of two situations. One is the challenges in corporate roles toward the institutional settings and the multinational agreements. The other is the gaps between the government actions and the industry standards in carrying out the environmental regulations and the international obligations. Data analyses also reveal that the population flux predominantly controls the magnitude of the $\mathrm{CO}_{2} \mathrm{e}$ emissions in a domain, although energy use and vehicle travels are among the leading factors in the road transport emissions.

In reference to the International Environmental Agency Standard, Environmental Commissioner of Ontario (2012) rants that global transportation emissions could potentially be reduced by $30 \%$ from current levels by 2050. In this case, sustainable environmental protection would need a three-tier strategic measure: technological improvement, non-technological measures, and transportation demand measures. Technological improvements may include improved fuel efficiency, the increased market diffusion of electro-mechanical vehicles, and the development of low-carbon alternative fuel, although the maintenance of industry standards would be challenging because of up-to-date manufacturing instruments at current state. Non-technological measures refer improved land use management preferably by transit-based land use planning to increase the use of environmentally sounds public transits by avoiding aggressive transportation-where acute vegetation coverage is an imperious efficacy to control the level of GHG emissions in carbon lands nexus in a region. Demand management measures in land transportation can aid to drive further reductions by lowering vehicle use. These strategies would be applicable for regional transport sector to fulfil the common goals of the countries where the effectiveness of environmental policy is yet impassable to the bearable measures in GHG emissions control.

In the long run, integrated transport policy can play a vital role to reduce $\mathrm{CO}_{2} \mathrm{e}$ emission, as local and global air pollution, from passenger transport considering the compliance with safety and standard regulations and multi-criteria analyses considering the CIPP model. As the public transportation is a crucial goal to generating an environmental friendly sustainable mobility (Environment Canada, 2010), there is a necessity for rethinking the needs for environmental awareness and campaign in Ontario especially at the local level, e.g., the municipal agencies to control the traffic volume. Significant change in policy and planning brings the perception of more informed decision and better situation to realize sustainability, environmental issues, and the importance of transit and alternative travel modes. A sustainable mobility model, in other words, the land 
transport models can also be adopted to control GHG emissions and to enhance the climate-smart land use with permissible vegetation coverage toward the economic and social benefits.

Nevertheless, empirical evidence, based on different public sectors' records, shows that the enterprises in the area of vehicle pollution control had reduced emissions of carbon monoxide and hydrocarbons in the transportation sector over the last decade. This research also recognizes that Ontario road transportation demonstrates a slight effectiveness in environmental protection performance, in terms of change or variation in percent, as compared with the federal (nationwide) state in GHG emissions produced from the road transportation sector and the total economic sectors as based on data from 1988/1990 to 2008. The findings presented in this paper also suggest a comprehensive examination to develop a regional GHG emission forecasting model to combate the $\mathrm{CO}_{2} \mathrm{e}$ emissions effects at the local level and to support the federal government commitments associated to the international accords in environmental pollution protection.

\section{References}

Bandhauer, K., Curti, J., \& Miller, C. (2005). Challenges to regulatory harmonization and standard-setting: The case of environmental accounting in the US and Canada. Journal of Comparative Policy Analysis, 7(2), 177-194.

Bates, J. C., Bibler, G. A., \& Blacmar, D. S. (1990). Doing business under Canadian environmental law. Northwestern Journal of International Law \& Business, 11(1), 1-46.

Bergeron, J., Halloway, L. B., Murphy, G. F., Elbert, C., Andrew, M. J., \& Snell, S. (2006). International transportation laws. International Transportation Laws, 4(2), 403-415.

CBC (Canadian Broadcasting Corporation) News. (2010). Canada, U.S. unites on car emission standards. Retrieved from http://www.cbc.ca/news/canada/story/2010/04/01/vehicle-emissions-ottawa-washington.html

Conference Board of Canada. (2013). Green house gas (GHG) emissions. The Conference Board of Canada.

Douglas, K., \& Hebert, M. (1999). The Canadian Environmental Protection Act. Parliament of Canada, Law and Government Division, April 21, 1998, revised in July 5, 1999.

Environment Canada. (2010). Planning for sustainable future: A federal sustainable development strategy for Canada. Sustainable Development Office, Environment Canada.

Environment Canada. (2013a). Canada's emission trends. Retrieved from http://www.ec.gc.ca/ges-ghg/985F05FB4744-4269-8C1A-D443F8A86814/1001-Canada\%27s\%20Emissions\%20Trends\%202013_e.pdf

Environment Canada. (2013b). National greenhouse gas emissions. Environmental Indicators. Air and Climate Indicators. Environment Canada (modified in April 17, 2015).

Environmental Commissioner of Ontario. (2012). A question of commitment-Review of the Ontario Government's Climate Change Action Plan Results. Annual Greenhouse Progress Report 2012.

Friesen, L. (2003). Targeting enforcement and environmental compliance with environmental regulations. Journal of Environmental Economics and Management, 46, 72-85.

Hazopoulou, M., \& Miller, E. J. (2008). Institutional integration of sustainable transportation policy in Canada. Transport Policy, 15(2008), 149-162.

Mertens, D. M., \& Wilson, A. T. (2012). Program evaluation theory and practice: A comprehensive guide. New York: The Guilford Press.

Monahan, P. J. (2006). Constitutional law: Essentials of Canadian Law (3rd ed.). Toronto, ON: Irwin Law Inc.

Moore, D. S. (2010). The basic practice of statistics (5th ed.). New York: W.H. Freeman and Company.

Munda, G., Nijkamp, P., \& Rietveld, P. (1994). Qualitative multicriteria evaluation for environmental management. Ecological Economics, 10(2), 97-112.

Natural Resources Canada. (2012). Comprehensive energy use database table-Transportation sector-Ontario, Table 9: Road transportation secondary energy use and ghg emissions by energy source.

Nemetz, P. N. (1986). Federal environmental regulation in Canada. Natural Resources Journal, 26, 551-608.

Norman, J., Maclean, H. L., \& Kennedy, C. A. (2006). Comparing high and low residential density: Life-cycle analysis of energy use and greenhouse gas emissions. Journal of Urban Planning and Development, 132(1), 10-21. 
Ontario Ministry of Transportation (MTO). (2008). Provincial highways traffic volume. Highways standard branch-Summary of accident data, 1988-2008. Ministry of Transportation, Ontario.

Orr, P. J., Emerson, K., \& Keyes, D. (2008). Environmental conflict resolution practice and performance: An evaluation framework. Conflict Resolution Quarterly, 25(3), 283-301.

Ortolano, L., \& Shepherd, A. (2012). Environmental impact assessment: Challenges and opportunities. Impact Assessment, 13(1), 3-30.

Peachlke, R. (2012). Regulatory and non-regulatory approaches to environmental protection. Canadian Public Administration, 99(1), 17-36.

Poudenx, P. (2008). The effect of transportation policies on energy consumption and greenhouse gas emission from urban passenger transportation. Poudenx/Transportation Research (Part A), 42(6), 901-909.

Rugman, A., \& Verbeke, A. (1998). Alain corporate strategy and international environmental policy. Journal of International Business Studies, 29(4), 819-833.

Santos, G., Behrendt, H., \& Teytelboym, A. (2010). Part-II: Policy instrument for sustainable road transport. Research in Transportation Economics, 28, 46-91.

Statistics Canada. (2012). CANSIM Database: Table 051-0001.

Terrell, S. R. (2012). Statistics translated: A step-by-step guide analyzing and interpreting data. New York: The Guilford Press.

Transport Canada. (2013). Transportation in Canada 2013: Overview report. Retrieved from http://www.tc.gc.ca/media/ documents/policy/Transportation_in_Canada_2013_eng_ACCESS.pdf

Tzeng, G.-H., Lin, C.-W., \& Opricovic, S. (2005). Multi-criteria analysis of alternative-fuel buses for public transportation. Energy Policy, 33, 1373-1383.

Wholey, J. S., Hatry, H. P., \& Newcomer, K. E. (Eds.). (2010). Handbook of practical program evaluation (3rd ed.). Toronto, ON: John Wiley \& Sons, Inc. 
Appendix A: Historical Data

\begin{tabular}{|c|c|c|c|c|}
\hline Year & $\begin{array}{r}\text { Population } \\
\text { (number) }\end{array}$ & $\begin{array}{r}\text { Energy Use, } \\
\text { PJ }\end{array}$ & $\begin{array}{l}\text { Vehicle } \\
\text { Travels, } \\
\text { MVKm }\end{array}$ & $\begin{array}{r}\text { GHG } \\
\text { Emissions, } \\
\text { megatonnes }\end{array}$ \\
\hline 1988 & $9,838,620$ & 442.27 & 72,345 & \\
\hline 1989 & $10,103,305$ & 479.64 & 76,917 & \\
\hline 1990 & $10,295,832$ & 517.00 & 73,341 & 35.60 \\
\hline 1991 & $10,431,316$ & 498.60 & 72,690 & 34.40 \\
\hline 1992 & $10,572,205$ & 513.40 & 73,304 & 35.40 \\
\hline 1993 & $10,690,038$ & 529.40 & 75,292 & 36.80 \\
\hline 1994 & $10,819,146$ & 540.40 & 78,167 & 37.70 \\
\hline 1995 & $10,950,119$ & 552.50 & 78,898 & 38.50 \\
\hline 1996 & $11,082,903$ & 557.30 & 79,368 & 38.90 \\
\hline 1997 & $11,227,651$ & 590.10 & 81,732 & 41.30 \\
\hline 1998 & $11,365,901$ & 607.20 & 84,478 & 42.40 \\
\hline 1999 & $11,504,759$ & 638.50 & 88,586 & 44.50 \\
\hline 2000 & $11,683,290$ & 658.00 & 117,834 & 45.90 \\
\hline 2001 & $11,896,663$ & 650.80 & 115,943 & 45.50 \\
\hline 2002 & $12,091,029$ & 665.80 & 123,683 & 46.60 \\
\hline 2003 & $12,242,273$ & 683.70 & 116,322 & 47.80 \\
\hline 2004 & $12,390,599$ & 702.90 & 122,079 & 49.00 \\
\hline 2005 & $12,528,480$ & 724.20 & 125,102 & 50.30 \\
\hline 2006 & $12,665,346$ & 705.10 & 130,392 & 48.70 \\
\hline 2007 & $12,791,032$ & 719.30 & 125,287 & 49.10 \\
\hline 2008 & $12,932,480$ & 717.60 & 124,673 & 49.10 \\
\hline
\end{tabular}

Figure A-1. Historical data of total population, energy use, vehicle travels, and GHG emissions in road transportation in Ontario region, 1988-2008. Sources: Statistics Canada (2012); Natural Resources Canada (2012); Ontario Ministry of Transportation (2008). Notes. Population numbers are from Statistics Canada (2012); GHG emissions, $\mathrm{CO}_{2} \mathrm{e}$, and energy use are from Natural Resources Canada (2012); vehicle travels indicate data of Ontario Ministry of Transportation (2008). 


\begin{tabular}{|c|c|c|c|c|c|}
\hline Year & $\begin{array}{r}\text { Total } \\
\text { Population } \\
\text { (number) }\end{array}$ & $\begin{array}{l}\text { Vehicle } \\
\text { Travels, } \\
\text { MVKm }\end{array}$ & $\begin{array}{r}\text { Road } \\
\text { Transportation } \\
\text { GHG Emissions, } \\
\text { megatonnes }\end{array}$ & $\begin{array}{r}\text { Road } \\
\text { Transportation } \\
\text { Energy Use, } \\
\mathrm{PJ} \\
\end{array}$ & $\begin{array}{r}\text { All Economic } \\
\text { Sectors- GHG } \\
\text { Emissions, } \\
\text { megatonnes }\end{array}$ \\
\hline 1988 & $26,791,747$ & $3,112,595$ & & & \\
\hline 1989 & 27,276,781 & 3,278,696 & & & \\
\hline 1990 & $27,691,138$ & 3,398,531 & 99.40 & $1,441.10$ & 589 \\
\hline 1991 & $28,037,420$ & $3,448,282$ & 96.20 & $1,390.20$ & 583 \\
\hline 1992 & $28,371,264$ & 3,512,983 & 98.50 & $1,422.70$ & 599 \\
\hline 1993 & $28,684,764$ & $3,624,400$ & 102.00 & $1,465.20$ & 601 \\
\hline 1994 & $29,000,663$ & $3,693,884$ & 107.50 & $1,539.90$ & 622 \\
\hline 1995 & 29,302,311 & 3,835,199 & 109.90 & $1,572.90$ & 639 \\
\hline 1996 & $29,610,218$ & 3,883,969 & 111.30 & $1,591.90$ & 657 \\
\hline 1997 & $29,905,948$ & $4,007,068$ & 116.00 & $1,655.30$ & 671 \\
\hline 1998 & $30,155,173$ & $4,133,058$ & 119.00 & $1,701.70$ & 678 \\
\hline 1999 & $30,401,286$ & 4,221,539 & 122.10 & $1,747.00$ & 691 \\
\hline 2000 & $30,685,730$ & 4,329,804 & 123.40 & $1,764.60$ & 718 \\
\hline 2001 & $31,019,020$ & 4,432,604 & 123.60 & $1,763.60$ & 711 \\
\hline 2002 & $31,353,656$ & $4,509,835$ & 126.20 & $1,800.70$ & 718 \\
\hline 2003 & $31,639,670$ & 4,602,715 & 130.70 & $1,864.20$ & 739 \\
\hline 2004 & $31,940,676$ & 4,659,561 & 134.80 & $1,929.90$ & 751 \\
\hline 2005 & $32,245,209$ & 4,775,923 & 136.00 & $1,953.20$ & 740 \\
\hline 2006 & $32,576,074$ & 4,827,843 & 135.50 & $1,955.00$ & 726 \\
\hline 2007 & $32,927,517$ & 4,853,937 & 140.80 & 2,037.10 & 751 \\
\hline 2008 & $33,317,662$ & $4,879,578$ & 141.00 & $2,046.40$ & 731 \\
\hline
\end{tabular}

Figure A-2. Historical data of total population, energy use, vehicle travels, and GHG emissions in road transportation and GHG emissions in all economic sectors in Canada, 1988-2008. Sources: Statistics Canada (2012); Natural Resources Canada (2012). Notes. Population data are from Statistics Canada (2012); road transportation GHG emissions, vehicle travels, and all economic sectors GHG Emissions indicate data from Natural Resources Canada (2012). 
Appendix B: Comparison of Generated Data and Correlations of Variables

A. Ontario (province / region)

\begin{tabular}{lrrrrr}
\hline & & & $\begin{array}{r}\text { Road } \\
\text { Transportati } \\
\text { on Energy } \\
\text { Use, PJ }\end{array}$ & $\begin{array}{r}\text { Vehicle } \\
\text { Travels, } \\
\text { MVKm }\end{array}$ & $\begin{array}{r}\text { Transportation } \\
\text { GHG } \\
\text { Emissions, } \\
\text { megatonnes }\end{array}$ \\
\hline Year & 1 & & & & \\
Population (number) & 0.999 & 1 & & & \\
Road Transportation Energy & 0.982 & 0.982 & 1 & & \\
Use, PJ & & & & & \\
Vehicle Travels, MVKm & 0.929 & 0.936 & 0.953 & & \\
Road Transportation GHG & 0.975 & 0.974 & $\mathbf{0 . 9 9 8}$ & $\mathbf{0 . 9 4 9}$ & \\
Emissions, megatonnes & & & & & \\
\hline
\end{tabular}

B. Canada (federal / national)

\begin{tabular}{|c|c|c|c|c|c|}
\hline & Year & $\begin{array}{r}\text { Total } \\
\text { Population } \\
\text { (number) }\end{array}$ & $\begin{array}{r}\text { Canada } \\
\text { Road } \\
\text { Transportati } \\
\text { on Energy } \\
\text { Use, } P J\end{array}$ & $\begin{array}{c}\text { Vehicle } \\
\text { Travels, } \\
\text { MVKm }\end{array}$ & $\begin{array}{r}\text { Canada Road } \\
\text { Transportation } \\
\text { GHG } \\
\text { Emissions, } \\
\text { megatonnes }\end{array}$ \\
\hline Year & 1 & & & & \\
\hline Total Population (number) & 0.999 & 1 & & & \\
\hline $\begin{array}{l}\text { Canada Road Transportation } \\
\text { Energy Use, PJ }\end{array}$ & 0.993 & 0.991 & 1 & & \\
\hline Vehicle Travels, MVKm & 0.996 & 0.995 & 0.990 & 1 & \\
\hline $\begin{array}{l}\text { Canada Road Transportation } \\
\text { GHG Emissions, megatonnes }\end{array}$ & 0.992 & 0.990 & 0.999 & 0.992 & 1 \\
\hline $\begin{array}{l}\text { All Economic Sector- } \\
\text { Emissions CO2e }\end{array}$ & 0.958 & 0.951 & 0.963 & 0.974 & 0.973 \\
\hline
\end{tabular}

Figure B-1. Correlations of road transport gas emissions $\mathrm{CO}_{2} \mathrm{e}$ and other variables. 
Percent Increased or

Decreased (based on

Geographical Area: Components /

Variables

\begin{tabular}{cccccc}
\multicolumn{3}{c}{ Year(s) } & & \multicolumn{2}{c}{ 1988) } \\
\cline { 1 - 2 } \cline { 5 - 6 } $1988 / 1990$ & 1998 & 2008 & & In $1998 \quad$ In 2008 \\
\hline
\end{tabular}

Ontario:

Population (number)

$\begin{array}{lllll}9,838,620 & 11,365,901 & 12,932,480 & 15.5 & 31.4\end{array}$

Energy Use, PJ

517.0

607.2

717.6

$17.4 \quad 38.8$

Vehicle Travels, MVKm

72,345

84,478

124,673

$16.8 \quad 72.3$

Road Transport $\mathrm{CO}_{2} \mathrm{e}$ Megatonnes

35.6

42.4

49.1

$19.1 \quad 37.9$

\section{Canada:}

Total Population (number)

$\begin{array}{rrrrr}26,791,747 & 30,155,173 & 33,317,662 & 12.6 & 24.4 \\ 1,441.1 & 1,701.7 & 2,046.4 & 18.1 & 42.0 \\ 3,112,595 & 4,133,058 & 4,879,578 & 32.8 & 56.8\end{array}$

Road Transport $\mathrm{CO}_{2} \mathrm{e}$ Megatonnes

99.4

119.0

141.0

$19.7 \quad 41.9$

All Economic Sectors $\mathrm{CO}_{2} \mathrm{e}$ Megatonnes

589.0

678.0

731.0

$15.1 \quad 24.1$

Figure B-2. Relative trends in gas emissions in transports in comparison with vehicle travels and total population in Ontario and Canada. Sources: Figure A-1 and Figure A-2 in Appendix A. 


\begin{tabular}{|c|c|c|c|c|c|c|c|c|c|c|}
\hline & & \multicolumn{3}{|c|}{ Ontario Road Transport } & \multicolumn{2}{|c|}{$\begin{array}{c}\mathrm{CO}_{2} \mathrm{e} \text { Emissions, } \mathrm{Mt} \\
\text { Per Million Population } \\
\end{array}$} & \multicolumn{2}{|c|}{$\begin{array}{c}\text { Percent Change in } \\
\text { Emissions }\end{array}$} & \multicolumn{2}{|c|}{$\begin{array}{l}\text { Percent Change in } \\
\text { Population }\end{array}$} \\
\hline Year & $\begin{array}{r}\text { Ontario } \\
\text { Population } \\
\text { as } \\
\text { Proportion } \\
\text { to } \\
\text { Canada's } \\
\text { total } \\
\text { population, } \\
\text { percent } \\
\end{array}$ & $\begin{array}{r}\text { Energy Use } \\
\text { as } \\
\text { proportion } \\
\text { of Canada's } \\
\text { road } \\
\text { transport } \\
\text { Energy } \\
\text { Use, } \\
\text { percent } \\
\text { (y5) }\end{array}$ & $\begin{array}{r}\mathrm{CO}_{2 \mathrm{e}} \\
\text { Emissions } \\
\text { as } \\
\text { proportion } \\
\text { to Canada's } \\
\text { road } \\
\text { transport } \\
\text { emissions, } \\
\text { percent (y6) } \\
\end{array}$ & $\begin{array}{r}\text { CO2e } \\
\text { Emissions } \\
\text { as } \\
\text { proportion } \\
\text { to } \\
\text { Canada's } \\
\text { all sectors' } \\
\text { emissions, } \\
\text { percent } \\
\text { (y7) } \\
\end{array}$ & $\begin{array}{r}\text { Ontario } \\
\text { Road } \\
\text { Transport } \\
\text { emissions } \\
(y 8) \\
\end{array}$ & $\begin{array}{r}\text { Canada } \\
\text { Road } \\
\text { Transport } \\
\text { emissions } \\
\text { (y9) } \\
\end{array}$ & $\begin{array}{r}\text { Ontario } \\
\text { Road } \\
\text { Transport } \\
\text { (y9) } \\
\end{array}$ & $\begin{array}{r}\text { Canada } \\
\text { Road } \\
\text { Transport } \\
(\mathrm{y} 10) \\
\end{array}$ & $\begin{array}{r}\text { Ontario } \\
(\mathrm{y} 11) \\
\end{array}$ & $\begin{array}{r}\text { Canada } \\
(12) \\
\end{array}$ \\
\hline \multicolumn{11}{|l|}{1988} \\
\hline 1989 & 37.04 & & & & & & & & 2.69 & 1.81 \\
\hline 1990 & 37.18 & 35.88 & 35.81 & 6.04 & 3.46 & 3.59 & & & 1.91 & 1.52 \\
\hline 1991 & 37.20 & 35.87 & 35.76 & 5.90 & 3.30 & 3.43 & -3.37 & -3.22 & 1.32 & 1.25 \\
\hline 1992 & 37.26 & 36.09 & 35.94 & 5.91 & 3.35 & 3.47 & 2.91 & 2.39 & 1.35 & 1.19 \\
\hline 1993 & 37.27 & 36.13 & 36.08 & 6.12 & 3.44 & 3.56 & 3.95 & 3.55 & 1.11 & 1.10 \\
\hline 1994 & 37.31 & 35.09 & 35.07 & 6.06 & 3.48 & 3.71 & 2.45 & 5.39 & 1.21 & 1.10 \\
\hline 1995 & 37.37 & 35.13 & 35.03 & 6.03 & 3.52 & 3.75 & 2.12 & 2.23 & 1.21 & 1.04 \\
\hline 1996 & 37.43 & 35.01 & 34.95 & 5.92 & 3.51 & 3.76 & 1.04 & 1.27 & 1.21 & 1.05 \\
\hline 1997 & 37.54 & 35.65 & 35.60 & 6.15 & 3.68 & 3.88 & 6.17 & 4.22 & 1.31 & 1.00 \\
\hline 1998 & 37.69 & 35.68 & 35.63 & 6.25 & 3.73 & 3.95 & 2.66 & 2.59 & 1.23 & 0.83 \\
\hline 1999 & 37.84 & 36.55 & 36.45 & 6.44 & 3.87 & 4.02 & 4.95 & 2.61 & 1.22 & 0.82 \\
\hline 2000 & 38.07 & 37.29 & 37.20 & 6.39 & 3.93 & 4.02 & 3.15 & 1.06 & 1.55 & 0.94 \\
\hline 2001 & 38.35 & 36.90 & 36.81 & 6.40 & 3.82 & 3.98 & -0.87 & 0.16 & 1.83 & 1.09 \\
\hline 2002 & 38.56 & 36.97 & 36.93 & 6.49 & 3.85 & 4.03 & 2.42 & 2.10 & 1.63 & 1.08 \\
\hline 2003 & 38.69 & 36.68 & 36.57 & 6.47 & 3.90 & 4.13 & 2.58 & 3.57 & 1.25 & 0.91 \\
\hline 2004 & 38.79 & 36.42 & 36.35 & 6.52 & 3.95 & 4.22 & 2.51 & 3.14 & 1.21 & 0.95 \\
\hline 2005 & 38.85 & 37.08 & 36.99 & 6.80 & 4.01 & 4.22 & 2.65 & 0.89 & 1.11 & 0.95 \\
\hline 2006 & 38.88 & 36.07 & 35.94 & 6.71 & 3.85 & 4.16 & -3.18 & -0.37 & 1.09 & 1.03 \\
\hline 2007 & 38.85 & 35.31 & 34.87 & 6.54 & 3.84 & 4.28 & 0.82 & 3.91 & 0.99 & 1.08 \\
\hline 2008 & 38.82 & 35.07 & 34.82 & 6.72 & 3.80 & 4.23 & 0.00 & 0.14 & 1.11 & 1.18 \\
\hline
\end{tabular}

Figure B-3. Total population, energy usages, and gas emissions distribution, 1988-2008 in Canada and the Ontario region. Sources: Statistics Canada (2012); Natural Resources Canada (2012). Note. Data calculated from Figure A-1 and Figure A-2 in Appendix A. 


\begin{tabular}{|c|c|c|c|c|c|c|c|c|c|c|c|}
\hline & Year & $\begin{array}{r}\text { Ontario } \\
\text { Population } \\
\text { as } \\
\text { Proportion } \\
\text { to Canada's } \\
\text { total } \\
\text { population, } \\
\text { percent } \\
\end{array}$ & $\begin{array}{r}\text { Ontario } \\
\text { Road } \\
\text { Transport: } \\
\text { Energy Use } \\
\text { as } \\
\text { proportion } \\
\text { of Canada's } \\
\text { road } \\
\text { transport } \\
\text { Energy Use, } \\
\text { percent (y5) }\end{array}$ & $\begin{array}{r}\text { Ontario } \\
\text { Road } \\
\text { Transport: } \\
\text { CO2e } \\
\text { Emissions } \\
a s \\
\text { proportion } \\
\text { to Canada's } \\
\text { road } \\
\text { transport } \\
\text { emissions, } \\
\text { percent (y6) }\end{array}$ & $\begin{array}{r}\text { Ontario } \\
\text { Road } \\
\text { Transport: } \\
\text { CO2e } \\
\text { Emissions } \\
a s \\
\text { proportion } \\
\text { to Canada's } \\
\text { all sectors' } \\
\text { emissions, } \\
\text { percent (y7) }\end{array}$ & $\begin{array}{r}\text { CO2e } \\
\text { Emissions, } \\
\text { Mt Per } \\
\text { Million } \\
\text { Population: } \\
\text { Ontario } \\
\text { Road } \\
\text { Transport } \\
\text { emissions } \\
(y 8)\end{array}$ & $\begin{array}{r}\text { CO2e } \\
\text { Emissions, } \\
\text { Mt Per } \\
\text { Million } \\
\text { Population: } \\
\text { Canada } \\
\text { Road } \\
\text { Transport } \\
\text { emissions } \\
(y 9)\end{array}$ & $\begin{array}{r}\text { Percent } \\
\text { Change in } \\
\text { Emissions: } \\
\text { Ontario } \\
\text { Road } \\
\text { Transport } \\
(y 9)\end{array}$ & $\begin{array}{r}\text { Percent } \\
\text { Change in } \\
\text { Emissions: } \\
\text { Canada } \\
\text { Road } \\
\text { Transport } \\
(y 10)\end{array}$ & $\begin{array}{r}\text { Percent } \\
\text { Change in } \\
\text { Population } \\
\text { : Ontario } \\
\text { (y11) }\end{array}$ & $\begin{array}{r}\text { Percent } \\
\text { Change in } \\
\text { Populatio } \\
n: \text { Canada } \\
(12)\end{array}$ \\
\hline Year & 1.000 & & & & & & & & & & \\
\hline $\begin{array}{l}\text { Ontario Population as } \\
\text { Proportion to Canada's total } \\
\text { population, percent }\end{array}$ & 0.969 & 1.000 & & & & & & & & & \\
\hline $\begin{array}{l}\text { Ontario Road Transport: } \\
\text { Energy Use as proportion of } \\
\text { Canada's road transport } \\
\text { Energy Use, percent (y5) }\end{array}$ & 0.224 & 0.374 & 1.000 & & & & & & & & \\
\hline $\begin{array}{l}\text { Ontario Road Transport: } \\
\text { CO2e Emissions as proportion } \\
\text { to Canada's road transport } \\
\text { emissions, percent (y6) }\end{array}$ & 0.154 & 0.305 & 0.993 & 1.000 & & & & & & & \\
\hline $\begin{array}{l}\text { Ontario Road Transport: } \\
\text { CO2e Emissions as proportion } \\
\text { to Canada's all sectors' } \\
\text { emissions, percent (y7) }\end{array}$ & 0.929 & 0.939 & 0.422 & 0.362 & 1.000 & & & & & & \\
\hline $\begin{array}{l}\text { CO2e Emissions, Mt Per } \\
\text { Million Population: Ontario } \\
\text { Road Transport emissions (y8) }\end{array}$ & 0.869 & 0.873 & 0.548 & 0.504 & 0.899 & 1.000 & & & & & \\
\hline $\begin{array}{l}\text { CO2e Emissions, Mt Per } \\
\text { Million Population: Canada } \\
\text { Road Transport emissions (y9) }\end{array}$ & 0.965 & 0.930 & 0.264 & 0.204 & 0.919 & 0.941 & 1.000 & & & & \\
\hline $\begin{array}{l}\text { Percent Change in Emissions: } \\
\text { Ontario Road Transport (y9) }\end{array}$ & -0.182 & -0.235 & 0.144 & 0.173 & -0.104 & 0.127 & -0.011 & 1.000 & & & \\
\hline $\begin{array}{l}\text { Percent Change in Emissions: } \\
\text { Canada Road Transport (y10) }\end{array}$ & -0.043 & -0.097 & -0.170 & -0.158 & -0.077 & 0.076 & 0.090 & 0.752 & 1.000 & & \\
\hline $\begin{array}{l}\text { Percent Change in Population: } \\
\text { Ontario (y11) }\end{array}$ & -0.497 & -0.373 & 0.412 & 0.443 & -0.232 & -0.094 & -0.281 & -0.017 & -0.221 & 1.000 & \\
\hline $\begin{array}{l}\text { Percent Change in Population: } \\
\text { Canada (12) }\end{array}$ & -0.562 & -0.460 & -0.296 & -0.296 & -0.400 & -0.619 & -0.535 & -0.507 & -0.354 & 0.762 & 1.00 \\
\hline
\end{tabular}

Figure B-4. Correlations among the redistributive and coherent variables. Sources: Statistics Canada (2012); Natural Resources Canada (2012). Note. Original data are in Figure A-1 and Figure A-2. 
Appendix C: Statistical Regression Analysis

SUMMARY OUTPUT

\begin{tabular}{lr}
\hline \multicolumn{2}{c}{ Regression Statistics } \\
\hline Multiple R & 0.9992 \\
R Square & 0.9984 \\
Adjusted R Square & 0.9978 \\
Standard Error & 0.2602 \\
Observations & 19.0000 \\
\hline
\end{tabular}

\begin{tabular}{|c|c|c|c|c|c|c|}
\hline & $d f$ & SS & MS & $F$ & ignificance $F$ & \\
\hline Regression & 5.0000 & 541.5366 & 108.3073 & $1,599.5518$ & 0.0000 & \\
\hline Residual & 13.0000 & 0.8802 & 0.0677 & & & \\
\hline Total & 18.0000 & 542.4168 & & & & \\
\hline & & Standard & & & & \\
\hline & Coefficients & Error & t Stat & P-value & Lower 95\% & Upper 95\% \\
\hline Intercept & 93.1082 & 522.2683 & 0.1783 & 0.8613 & $-1,035.1839$ & $1,221.4003$ \\
\hline Year & -0.0478 & 0.2722 & -0.1755 & 0.8634 & -0.6359 & 0.5404 \\
\hline Ontario Population $^{1}$ (number) & 0.0000 & 0.0000 & -0.3174 & 0.7560 & 0.0000 & 0.0000 \\
\hline Ontario Road Transportation Energy Use ${ }^{2}$, PJ & 0.0649 & 0.0063 & 10.3363 & 0.0000 & 0.0513 & 0.0785 \\
\hline Ontario Vehicle Travels ${ }^{3}$, MVKm & 0.0000 & 0.0000 & 0.3196 & 0.7544 & 0.0000 & 0.0000 \\
\hline All Economic Sectors- GHG Emissions ${ }^{10}$, Mt & 0.0172 & 0.0056 & 3.0956 & 0.0085 & 0.0052 & 0.0292 \\
\hline
\end{tabular}

RESIDUAL OUTPUT
PROBABILITY OUTPUT

\begin{tabular}{rr}
\hline & $\begin{array}{r}\text { Ontario Road } \\
\text { Transportation } \\
\text { GHG }\end{array}$ \\
& ${ }^{4}, M t$ \\
\hline Percentile & Emissions ${ }^{\text {M }}$. \\
\hline 2.6316 & 34.4000 \\
7.8947 & 35.4000 \\
13.1579 & 35.6000 \\
18.4211 & 36.8000 \\
23.6842 & 37.7000 \\
28.9474 & 38.5000 \\
34.2105 & 38.9000 \\
39.4737 & 41.3000 \\
44.7368 & 42.4000 \\
50.0000 & 44.5000 \\
55.2632 & 45.5000 \\
60.5263 & 45.9000 \\
65.7895 & 46.6000 \\
71.0526 & 47.8000 \\
76.3158 & 48.7000 \\
81.5789 & 49.0000 \\
86.8421 & 49.1000 \\
92.1053 & 49.1000 \\
97.3684 & 50.3000 \\
\hline
\end{tabular}

Figure C-1. Multiple regression analysis-Ontario road transportation GHG emissions. 
SUMMARY OUTPUT- CANADA ROAD TRANSPORTATION

\begin{tabular}{lr}
\hline \multicolumn{2}{c}{ Regression Statistics } \\
\hline Multiple R & 0.9999 \\
R Square & 0.9997 \\
Adjusted R Square & 0.9996 \\
Standard Error & 0.2765 \\
Observations & 19.0000 \\
\hline
\end{tabular}

\begin{tabular}{|c|c|c|c|c|c|c|}
\hline \multicolumn{7}{|l|}{ ANOVA } \\
\hline & $d f$ & SS & $M S$ & $F$ & Significance F & \\
\hline Regression & 5.0000 & $3,895.8380$ & 779.1676 & $10,195.1341$ & 0.0000 & \\
\hline Residual & 13.0000 & 0.9935 & 0.0764 & & & \\
\hline \multirow[t]{3}{*}{ Total } & 18.0000 & 3,896.8316 & & & & \\
\hline & & Standard & & & & \\
\hline & Coefficients & Error & t Stat & P-value & Lower 95\% & Upper 95\% \\
\hline Intercept & $7,835.7359$ & $2,041.0448$ & 3.8391 & 0.0020 & $3,426.3266$ & $12,245.1452$ \\
\hline Year & -4.0993 & 1.0669 & -3.8423 & 0.0020 & -6.4041 & -1.7944 \\
\hline Canada Population ${ }^{6}$ (number) & 0.0000 & 0.0000 & 3.7491 & 0.0024 & 0.0000 & 0.0000 \\
\hline Canada Road Transportation Energy Use ${ }^{7}, \mathrm{PJ}$ & 0.0622 & 0.0029 & 21.7645 & 0.0000 & 0.0560 & 0.0684 \\
\hline Canada Vehicle Travels ${ }^{8}$, MVKm & 0.0000 & 0.0000 & 3.4972 & 0.0039 & 0.0000 & 0.0000 \\
\hline All Economic Sectors- GHG Emissions ${ }^{10}$, Mt & 0.0337 & 0.0063 & 5.3444 & 0.0001 & 0.0201 & 0.0473 \\
\hline
\end{tabular}

RESIDUAL OUTPUT

\begin{tabular}{rrrr}
\hline \multicolumn{5}{c}{$\begin{array}{c}\text { Predicted } \\
\text { Canada Road } \\
\text { Transportation } \\
\text { GHG }\end{array}$} & & \\
Observation & Emissions ${ }^{9}$, Mt & Residuals & Residuals \\
\hline 1 & 99.7501 & -0.3501 & -1.4900 \\
2 & 96.2687 & -0.0687 & -0.2924 \\
3 & 98.7685 & -0.2685 & -1.1428 \\
4 & 101.7628 & 0.2372 & 1.0098 \\
5 & 106.9355 & 0.5645 & 2.4025 \\
6 & 110.0750 & -0.1750 & -0.7448 \\
7 & 111.3615 & -0.0615 & -0.2618 \\
8 & 116.0211 & -0.0211 & -0.0900 \\
9 & 118.9635 & 0.0365 & 0.1555 \\
10 & 121.5721 & 0.5279 & 2.2470 \\
11 & 123.5360 & -0.1360 & -0.5789 \\
12 & 123.6153 & -0.0153 & -0.0650 \\
13 & 126.2520 & -0.0520 & -0.2212 \\
14 & 130.7061 & -0.0061 & -0.0261 \\
15 & 134.7223 & 0.0777 & 0.3305 \\
16 & 136.0537 & -0.0537 & -0.2287 \\
17 & 135.4555 & 0.0445 & 0.1893 \\
18 & 141.0682 & -0.2682 & -1.1414 \\
19 & 141.0121 & -0.0121 & -0.0516 \\
\hline
\end{tabular}

PROBABILITY OUTPUT

\begin{tabular}{rr} 
& \\
& $\begin{array}{r}\text { Canada Road } \\
\text { Transportation } \\
\text { GHG }\end{array}$ \\
Percentile & Emissions ${ }^{9}$, Mt \\
\hline 2.6316 & 96.2000 \\
7.8947 & 98.5000 \\
13.1579 & 99.4000 \\
18.4211 & 102.0000 \\
23.6842 & 107.5000 \\
28.9474 & 109.9000 \\
34.2105 & 111.3000 \\
39.4737 & 116.0000 \\
44.7368 & 119.0000 \\
50.0000 & 122.1000 \\
55.2632 & 123.4000 \\
60.5263 & 123.6000 \\
65.7895 & 126.2000 \\
71.0526 & 130.7000 \\
76.3158 & 134.8000 \\
81.5789 & 135.5000 \\
86.8421 & 136.0000 \\
92.1053 & 140.8000 \\
97.3684 & 141.0000 \\
\hline
\end{tabular}

Figure C-2. Multiple regression analysis-Canada road transportation GHG emissions. 